\title{
1. The Asia-Pacific, regionalism and the global system: an introduction
}

\section{Jörn Dosch and Christopher M. Dent}

\section{THE ASIA-PACIFIC IN THE WORLD}

Ever since the Asia-Pacific transformed from an 'institutional desert' into one of the most networked areas in the world, questions of the region's future and the future of the global system have become closely intertwined. The Asia-Pacific area, the world's largest 'trans-region', comprises three main regional constituents: East Asia, Pacific America (North and Latin American nations with a Pacific coast) and Oceania, for example Australia and New Zealand. It hosts around a half of the world's population and accounts for a similar proportion of the global economy. Individual countries from the region have significant global impact. The Asia-Pacific contains the world's three biggest economies (the United States, China and Japan), the world's largest military power (the US) and the world's most populous nation (China). The region is also home to eight of the world's ten largest military forces. Meetings between the 21 member economies of the Asia-Pacific Economic Cooperation (APEC) forum - the world's largest regional grouping - represent an important global constituency in a world increasingly defined and structured around regions, regional communities and regional powers. Recent and future endeavours to build a 'Pacific Community' could have a profound effect on all countries.

In fact, it was the founding of APEC in 1989 that triggered a novel process of institution-building and regionalism in the Asia-Pacific that was distinctly different from European experiences ${ }^{1}$ and seemed to provide answers for the then emerging 'new world order', a term coined by George W.H. Bush. Even without the US president's magic and vague words, an international debate about the basic structures of the post-Cold War world was necessary and inevitable at a time when an end-of-history spirit proved to be prevalent, with Fukuyama's position as shibboleth among the Western powers and elsewhere (Fukuyama 1992). This discourse was embedded in a widespread feeling of relief because a cluster of totalitarian and authoritarian states and their claim of a world revolution seemed 
to be fading away. The Soviet Empire simply dissolved, and this offered hope that a new and lasting peace, based on peoples' consent, would prosper worldwide on a basis of a consensual political order, shared values, free markets, and large economic networks. While contemporary observers might smile at this somewhat naïve neo-Wilsonian preposition of two decades ago, it would be wrong to conclude that the optimism and promises of the early 1990s went entirely unfulfilled. Structural features of the Cold War order, such as hegemony and unilateralism, still feature prominently in the Asia-Pacific, but in parallel the ongoing multilateralisation of international relations in the region has contributed to a sustained situation of relative peace and stability. At the same time this process has opened new windows for regional governance that have started to challenge the very foundations of the existing global system - for better or worse. As a recent high-level meeting of political practitioners and academics on the future of the international system, held under the Chatham House rule, concluded,

The rise of Asia and a rebalancing of global governance - with more power flowing to Asia - has created anxiety in the West about the future of that system. There are fears that 'the rise of the rest' will result in new global norms, new operating principles for global institutions, and different outcomes in international decision-making.

In addition to the ever-growing economic might of some East Asian nations, first and foremost China, and the potential implications for the prevailing balance of power in global organisations like the World Trade Organisation (WTO), International Monetary System (IMF) and World Bank, much of the discourse on the promises and challenges of 'Asia's rise' is driven by the uniqueness of the approaches to regional governance in the Asia-Pacific. First, contrary to transatlantic experiences and maybe for the first time in modern history, in the Asia-Pacific a multilateral system of interstate relations was initiated and continues to be significantly influenced by medium powers (ASEAN - Association of Southeast Asian Nations, South Korea, Japan, and to some extent Australia) and not by the dominant actors, particularly the United States. China has only recently begun to take a stronger interest in regional organisations but has increasingly put its mark on the shaping of regionalism. At the same time it is important to note that the role of the United States cannot be ignored in the process of regionalisation and multilateralisation, even though Washington did not spearhead the process and is excluded from some regional forums. Second, and equally if not more important, regionalism in the Asia-Pacific as manifested not only by APEC but also a growing number of other organisations and co-operation mechanisms such as 
ASEAN Plus Three (APT), East Asian Summit (EAS), ASEAN Regional Forum (ARF) and the China-Japan-Korea trilateral summit, stands for a model of regional co-operation that has emerged as an alternative to the European approach.

\section{REGIONALISM AND GLOBALISATION IN FOCUS}

While the European integration process is characterised by treaties and legally binding commitments, the Asia-Pacific has followed a non-legalistic approach to inter-governmental co-operation based on the so-called 'ASEAN way' of soft institutions, open regionalism, co-operative security, non-binding decision-making, convention and consensus-building. The ASEAN way is based on the premise that the moral power of informal procedures can determine relations between actors as effectively as legally binding rules. The former - so the argument goes - has allowed for more flexibility in dealing with specific policy challenges of regional governance than the latter. Empirically sound or not, the realities of intergovernmental co-operation in the Asia-Pacific have markedly shaped general discourses on regionalisation and regionalism.

The idea of the regionalisation of international relations refers to the underlying, often undirected, processes bringing adjoining states, societies and economies into intensified interaction. Through this interaction a particular cluster of states may be said to have a distinctive orientation to each other and may be said to constitute a region. The term regionalism is more complex. According to Joseph Nye, 'in the descriptive sense [it means] . . . the formation of interstate associations or groupings on the basis of regions; and in the doctrinal sense, the advocacy of such formations' (Nye 1968: vii). Thus, while regionalisation is what happens, regionalism can be understood as a conscious orientation by actors to bring about specific forms of regionalisation. In other words, 'we may refer to regionalism as the structures, processes and arrangements that are working towards greater coherence within a specific international region in terms of economic, political, security, socio-cultural and other kinds of linkages' (Dent 2008: 7).

In the debate on regionalism it has become commonplace to distinguish between an older generation of regionalism (under the label of 'regional integration' these were studies that mainly focused on the process of European integration) in the 1950s and 1960s, and a more recent new 'wave' of regionalism (the 'new regionalism') starting in the latter half of the 1980s. Traditional theories of regionalism (or 'old regionalism') 
are closely associated with scholarly work of the 1950s and 1960s, with Europe being the principal basis for empirical studies. David Mitrany (1943) and Jacob Viner (1950) are acknowledged as two of the most influential pioneers in this area. While Mitrany is considered the father of functionalism - that focuses on the common interests and needs shared by states and postulates a gradual transfer of authority and sovereignty from the state to a supranational level (that is, new regional agencies above the traditional nation states) in functional, technical and economic areas Viner made ground-breaking contributions to the analysis of international trade. His work was later refined and built upon by many other scholars like Béla Balassa (1961) who described regional economic integration a linear process over five different levels.

Apart from their focus on economic integration, 'old' theories or approaches to regionalism were predominately concerned with peace, and tended to see the nation-state as the problem rather than the solution. 'New regionalism' considers novel aspects, particularly those focused on conditions related to globalisation and is prominently linked to aspects of economic governance (Hettne 2005). As Harrison (2006) contended, 'New regionalists go so far as to claim that contemporary capitalism and its territorial configuration are best regulated and governed in and through the decentralisation of socioeconomic decision-making and associated policy implementation to sub-national institutional frameworks and supports' (p. 22). According to Hettne (1999), one of the main proponents of new regionalism, 'the two processes of globalisation and regionalisation are articulated within the same larger process of global structural change' (p. 2). Väyrynen (2003) further adds that 'national actors may ... perceive regionalism as a defence mechanism against the competitive pressures arising from the globalisation process' (p. 32). The Inter-American Development Bank (2002) has meanwhile observed that 'an increasing number of countries are relying on formal regional integration to mediate the forces of globalisation' (p. 24).

In addition to the strong linkages between the 'new regionalism' debate and discourses in international political economy, social constructivists have also discovered regionalism as a preferred empirical focus. There can be little doubt that a sense of regional consciousness has emerged in many world regions and that states have actively promoted the idea of mutual co-operation. Regardless of whether regions need to be defined in geographical terms or can also be thought of as socially constructed 'imagined or cognitive regions' (Väyrynen 2003: 37), identity is one of the most important and solid pillars of regionalism, no matter whether this pillar is based on a geographical concepts or has a foundation driven by norms and values. 
It is the regional-global nexus combined with the notion of cognitive regions that bears particular relevance to the Asia-Pacific. Little more than a decade ago, the East Asian developmental state and, linked to it, governance models and work ethics based on a crude understanding of political Confucianism, almost emerged as the gold standard for the efficient management of opportunities and challenges in the dawning, globalised 21st century and strongly contributed to the formation of an East Asian identity. The 'Asian values' debate served as a central piece in the explanatory puzzle as to why East Asian economies enjoyed tremendous economic growth and success. Nowhere else did the three main pillars of globalisation in the mainstream understanding of the concept - economic integration, domestic economic deregulation and rapid advances in technology - manifest themselves more clearly than in the post-World War II economic history of Northeast and Southeast Asia (Coclanis and Doshi 2000). East Asian self-confidence and a 'them versus us' mentality was the order of the day, with prominent political voices proclaiming the 'demise of European modernism' (Mahathir and Ishihara 1995) and academic observers discussing the dawn of the 'Pacific century' (Borthwick 1992) as well as a potentially looming 'obsoleteness of the West' (Elegant 1990). However, when the East Asian financial crisis of $1997 / 98$ shattered the dream of globalisation as a never-ending profit-generating phenomenon and forced the region into an economic downturn that also had farreaching political, social and ecological ramifications, the self-perception quickly changed, from being the champion of globalisation to being the first victim of the borderless, information-driven world. To many, the 1997/98 crisis, often dubbed the first crisis of globalisation (Higgott 1998), demonstrated in great clarity the link between national and regional corporate activities, and global economic organisations such as the World Bank and the IMF. Even those who did not subscribe to the idea of predatory global integration as the main factor behind the economic turmoil agreed that the 1997/98 East Asian financial crisis has had a fundamental impact on the perception of globalisation. The discourse shifted from the confrontational mode to a more sober analysis of the sovereignty of the state, centred on the argument that the manifold and simultaneous processes of globalisation were undermining the foundations of national sovereignty and reducing the capacity of policymakers to act autonomously or effectively within national jurisdictions (Beeson 2009). This, in turn, led to a new - and the most recent - phase in Asia-Pacific regionalism which has seen the rise of new institutional mechanisms to mitigate the regional impact of any future global crises, to deal more effectively with regional challenges and to foster the idea of community-building. The Chang Mai Initiative currency swap system (first a network of bilateral agreements, 
then multilateralised in 2010) and related attempts at strengthening monetary and financial co-operation largely through ASEAN Plus Three diplomacy, as well as initiatives to extend transpacific relations beyond APEC, such as in the case of the Forum for East Asia-Latin America Co-operation (FEALC) inaugurated in 2003, are clear manifestations of this new wave in Asia-Pacific regionalism (Beeson 2009, Dosch and Jacob 2010, Volz 2010). As Dieter (2009) argued, 'Overall, the Asian crisis has had a lasting influence on the region's institutional development . . . After the traumatic experience ..., the desire for greater independence required the exclusion of those countries that had done little to solve the problems created by the crisis' (p. 81).

The second and increasingly expanding pillar of region-wide (but not necessarily coherently regional) co-operation in the Asia-Pacific is bilateralism, particularly in the form of bilateral free trade agreements (FTAs) that have mushroomed since the late 1990s. The simultaneous intensification of economic bilateralism and multilateralism in the Asia-Pacific, which is constituent to the broader integrational trend of globalisation, has posed questions as to the compatibility of these two processes - a discourse that builds on the 'lattice regionalism' hypothesis: to what extent is trade bilateralism precursory to Asia-Pacific regionalism (Dent 2006)?

Studies on Asia-Pacific regionalism and its interface with globalisation are not new. However, the Asia-Pacific is such a fluid and dynamic region that it demands continual reappraisal and reconsideration. Communist, democratic and authoritarian regimes cohabit and coexist within the region, if not always peacefully. Many Cold War relics remain scattered throughout the Asia-Pacific. Taiwan remains a point of friction between the USA and China; the People's Republic of China remains a communist state, albeit one with many of the trappings of a capitalist market economy; the 1953 division of the two Korea states at the 38th parallel persists; and US military pre-eminence in the region continues. But can it co-exist with China's growing assertiveness in the region and indeed the world? We should not blind ourselves to the fact that the soft institutionalised Asia-Pacific regionalism is no safeguard against assertive hegemony and that the existing multilateral architecture is not immune to hegemomic co-operation (Dosch 2006), which is dominated by a state that 'holds a sufficiently decisive share of power assets to impose the distribution of benefits and costs it desires and international arrangements which make for that distribution' (Bobrow 1999: 175). However, there is a fine line between regional hegemony and leadership. It can be argued that it is precisely the lack of the latter that has hindered the Asia-Pacific from making more rapid progress towards a working system of regional governance. Any development towards a form of 'regulatory regionalism' (Jayasuriya 
2003; Hameiri and Jayasuriya 2011) in East Asia remains nascent. There is a growing gap between political rhetoric and actual policy implementation at the national level with regards to the emerging system of regional multilevel regulation as evidenced, for example, by the ASEAN regional surveillance process (ASP), which was endorsed by ASEAN Financial Ministers in 1998. Similar observations apply to regionalism in the realm of security. Political and public expectations vis-à-vis the steering capabilities of existing multilateral forums are often unrealistically high. The ASEAN Regional Forum, for instance, provides a valuable framework for communication in international relations which increases transparency and contributes to trust building; but the ARF has struggled to agree on any specific norms or even rules and procedures that go beyond the general interest of keeping the region peaceful and stable. The forum's institutional design has not allowed for the implementation of preventive diplomacy in the Asia-Pacific or any serious contribution to the long-term resolution of the Korean crisis or conflict-resolution in the case of the disputes in the South China Sea.

\section{STRUCTURE AND SUMMARY OF THE BOOK}

This volume sheds critical light on these and many other developments and delves into the key issues of regional governance, integration and international affairs within and across the Asia-Pacific. We ask how these developments are impacting on the global system, in particular on emerging forms of global governance. In short, this book looks at how the Asia-Pacific region is shaping the world. Unlike many other publications on similar topics our discussion is not limited to East Asia but takes Latin America prominently into the equation.

The book is structured along the following lines. After this introductory chapter in Part I, Part II examines different aspects of economic integration in the Asia-Pacific from regional and global perspectives. In Chapter 2, Melba Falck Reyes analyses Japanese manufacturing FDI in Mexico and the extent to which it has fostered international production network (IPN) activity in this part of Latin America, and thereby helped incorporate Mexico into broader regional and global business networks. In 2005, Mexico and Japan signed their landmark Economic Partnership Agreement (EPA), for each country their first trans-Pacific free trade agreement. Japan's motive was largely investment driven, its aim being to recover the privileged position that Japanese firms had under the Mexico's maquiladora policy, a privilege lost in 2001 when a special clause implemented under the North American Free Trade Agreement (NAFTA) 
eliminated the tariff-free import of parts and components outside the NAFTA region. The Japan-Mexico EPA helped restore the advantages of Japanese investors and led to a new spurt in Japanese manufacturing investment in Mexico. Decades before, Japanese companies had pioneered the development of international production networks in East Asia, these being embedded in larger global networks and supply chains. One consequence, then, of Japan's post-EPA increase in investment was to extend Japanese firms' IPN activity deeper into Mexico, and thereby bring the country into deeper cross-border integration with Japanese business networks in the United States and East Asia. This bilateral investment relationship thus had regional and cross-regional dimensions, this too being indicative of how global capital is organised.

Links between Latin America and East Asia are considered by José Luis León-Manríquez in Chapter 3, who discusses the different approaches that South Korea and Mexico have taken to dealing with the challenges of global trade, integration and economic crises. Special attention is paid to the 2008/09 global economic crisis. South Korea and Mexico are two similar sized economies, both notably dependent on manufacturing exports, and have had their own experiences with accommodating neoliberal reforms as well as significant financial crises - Mexico in 1994/95 and South Korea in 1997/98. Yet their responses to the 2008/09 global economic crisis were markedly different. León-Manríquez attributes this primarily to the contrasting political economies of each country that in turn are representative of broader regional political economy differences between East Asia and Latin America. He argues that South Korea's revitalised developmental state - centring on the substantial public funded new 'Green Growth' development strategy and associated 5-Year Plans - have proved more effective at navigating the economy through the crisis than the passive market-liberal approach pursued by Mexico. The South Korean state's response to the crisis is moreover indicative of a wider revitalisation of East Asian developmental statism and other forms of state capacity. Meanwhile, Mexico's entrenched market-liberalism is consistent with the dominance of US-led neo-liberal thinking that still pervades most of Latin America.

In Chapter 4, Arturo Santa-Cruz focuses on how the North America region was 'constructed' in the contexts of globalisation and regionbuilding. He asks the fundamental question of whether North America exists as a meaningful region: that is, do Canada, Mexico and the United States share perceptions regarding interests, threats and values. Furthermore, what does North America's regionalism and regionalisation experience tell us about globalisation and the regionalisation experience in the Asia-Pacific? In addressing these questions, Santa-Cruz discusses the twin concepts and processes of globalisation and regionalisation in some 
detail, and argues that while both processes are complementary, the latter remains a second-best outcome. He then considers these questions in relation to North America's, and thereby NAFTA's, engagement with APEC, providing insights on comparative region-building.

Part III of the book shifts the focus to key issues of regional and global multilateralism relating to the Asia-Pacific. In Chapter 5, John Ravenhill considers the 'numbers game' in Asia-Pacific co-operation. He observes that over the last few years an increasing discontent has been expressed about the effectiveness of existing regional institutions in the Asia-Pacific region. These criticisms have equally targeted institutions primarily concerned with security matters (for example ARF) and those primarily focused on economic issues, such as APEC. Criticisms have come not just from academics but also from government leaders and from think-tanks closely associated with governments, for example Indonesia's Centre for Strategic and International Studies. The depth of concern about existing regional institutions was evident in the 'regional community' proposals in the late 2000s from Japanese Prime Minister Yukio Hatoyama and Australian PM Kevin Rudd for a radical departure from the status quo. Both proposals, at least implicitly, attacked the ASEAN-centric character of existing regional institutions and proposed instead either that leadership be exercised by or membership be confined to 'regionally significant states'. Meanwhile at the global level the G20 of 'systemically significant economies' has been elevated to the status of the premier forum for managing the global economy. Through an examination of the recent experience of regional institutions, the fate of the Hatoyama and Rudd proposals, and the experience of the G20, Ravenhill explores the question of the relationship between selective membership and governability.

In Chapter 6, Yao Chaocheng applies the 'subsidiarity' principle, long associated with the European integration experience to that of Asia's own. He notes that a top-down, inter-governmental approach to driving forward Asian regionalism can only achieve so much. What is required is a mass, multi-level engagement of civil society and other non-state actors in a more bottom-up process where more localised support for regional integration projects can be more effectively mobilised. Yao argues that governments can take various measures to encourage and promote this, and that the greater socialisation of East Asian peoples will also improve relations between them and make valuable contributions to dealing with historic animosities that persist in the region. This, he contends, is consistent with the Subsidiarity principle of empowering localised actors to take greater ownership over regionalist initiatives and thereby underpin the macro-regionalism projects (for example free trade areas) proposed at the inter-state level. 
Hugo Dobson in Chapter 7 takes a close look at how Asian nations are engaging in the new G20 global-multilateral grouping. He notes that with the rise of the G20 as the premier forum for international economic co-operation as a result of the G8 group's expanded membership, a debate has begun over whether this will encourage greater co-operation between the six Asian group members of the G20, the so-called 'A6': Australia, China, India, Indonesia, Japan and South Korea. Dobson explores these prospects based on trends emerging from the five G20 summits held by May 2011. He also discusses the extent to which Asian countries are shaping the ongoing evolution of the G20, its agenda and its relationship to other mechanisms of global governance. In reviewing the position of each A6 country, Dobson observes that Australia has been one of the most proactive countries in advocating revision of the architecture of global governance and co-ordinating an Asian response therein. However, there are questions as regards how far it will promote these changes, in what form and to what end? In the case of China, it probably means more to the G20 than the G20 means to China. Dobson contends that what the G20 means to China can be understood mostly in terms of recognition rather than as an opportunity to provide global, let alone regional, leadership. Meanwhile, he notes that India has shown little inclination to lead or contribute to the G20's work, and Indonesia's concerns revolve around moving from the regional to global level but it continues to suffer from domestic problems that have the potential to undermine this ambition. For Japan, Dobson contends that the emergence of the G20 has presented a challenge rather than an opportunity. It has worked towards the success of the $\mathrm{G} 20$ as the 'premier forum for international economic cooperation', even demonstrating a leadership role on occasions, whilst displaying a reactionary preference for the G8 and the status that goes with membership of this more select grouping. Finally, South Korea's participation in the G20 is an opportunity to demonstrate its ability to provide leadership in global governance, particularly in the face of a number of doubters before the November 2010 Seoul Summit, and burnish President Lee Myun-bak's domestic legacy. Overall, Dobson argues that national interests have predominantly shaped the participation of the A6 members of the G20 thus far. There is no apparent common A6 agenda or caucus. Rather, fragmentation amongst the A6 can be seen both in participation, which has been largely unilateral, uncoordinated and driven by national interest and status anxiety, and in the issue of the evolving architecture of global governance.

The Asia-Pacific's position regarding the G8 and G20 relationship is further discussed by Hong Yousheng and Fang Qing in Chapter 8, who specifically consider how the expanded G20 will bring about shifts in the 
dynamics of global economic governance. Hong and Fang contend that if the G8 has been one key mechanism of global economic governance since it was formed by Western advanced countries in 1975, then its influence is declining nowadays due to the rise of new economic powers which are playing an increasingly important role in the world's economic growth, resulting in the appearance of the G20. While academia is focused on the debate of whether G8 could be replaced by G20 as a more effective mechanism of world governance, the concept of G2 or 'Chimerica' has also been proposed as the key axis of global economic governance in the early $21 \mathrm{st}$ century. Both the consolidation of the G20 over recent years and the idea of a $\mathrm{G} 2$ have been indicative of the global shift in economic and geopolitical power from the Atlantic to the Pacific. The Asia-Pacific accounts for half the G20's membership, hence this raises important questions for Hong and Fang concerning how the region will shape the future dynamics and structures of global governance.

This is followed in Chapter 9 by Jörn Dosch's analysis of how multilateral organisations in the Asia-Pacific responded to the 2008/09 global economic crisis. He analyses and compares the specific actions discussed, taken and implemented by two regional organisations - ASEAN and MERCOSUR (Southern Common Market) - and two inter-regional fora - APEC and FEALAC (Forum for Asia-Latin America Co-operation) - in response to the crisis. He compares the four organisations from two different angles. First, which of the two regional organisations, ASEAN or MERCOSUR, has been more efficient and effective in responding to the crisis and why? Second, which of the two multilateral co-operation structures, regionalism or inter-regionalism, has made the more significant contributions to countering the crisis? Dosch uses the theoretical discourse on regional integration and inter-regionalism as the analytical backdrop and challenges some of the existing mainstream arguments in this debate. In particular he argues that the academic literature almost completely neglects the role and influence of extra-regional actors, including foreign donors, in regional co-operation processes in both Asia and Latin America. However, as the chapter tries to demonstrate, regional and inter-regional responses to the crisis have been most successful when policy efforts were promoted, (financially) supported or even driven by extra-regional actors, such as European Union and US stakeholders.

In Chapter 10, Cheol Hee Park focuses in on the intra-regional geopolitical dynamics of Northeast Asia (China, Japan and Korea). He discusses the various issues relating to how a rising China presents both numerous opportunities and challenges its regional neighbours in Northeast Asia and the wider Asia-Pacific. Park discusses the contending perspectives regarding international responses to China's ascendance, ranging from 
balancing strategies to band-wagoning strategies. More specifically concerning Northeast Asia, South Korean and Japanese approaches have converging as well as diverging elements. As he observes, there is no difference in that China is a number one trading partner for both South Korea and Japan. Also, the two countries do not disagree to the point that functional co-operation among Northeast Asian countries should be advanced. However, when it comes to security-related issues, Park contends the two countries do not necessarily share the same approach. Several issues are involved in this dynamics such as historical controversy, the North Korean problem and regional integration. Park addresses the question of meeting the challenge of rising China in the eyes of South Korea and Japan for the purpose of finding implications for regional and global governance.

Part IV of the book examines how East Asian countries, especially China, are impacting on important aspects of global development. It begins with Jeffrey Henderson in Chapter 11 reflecting on the implications of the re-emergence of China as a global economic and political power for the nature of globalisation. As such, this chapter takes 'the global' seriously as a political-economic and socio-spatial formation that has real, semi-autonomous consequences for the lives and livelihoods of humanity. Henderson begins by arguing that globalisation is not a product of abstract, disembodied rules and practices that emanate from an idealised notion of capitalism, as much of the 'globalisation' literature implies. Rather, it can be traced - through various forms and phases to the concrete nature of the capitalisms that have dominated the given historical period. Globalisation, in other words, represents an attempt to forge the world in the image of its principal driving force. Having briefly demonstrated the link between the dominant form of capitalism and the form of globalisation in recent history, Henderson argues that with the rise of China and perhaps other Asian powers in its wake, we may be witnessing the emergence of a new form of globalisation, presaging perhaps, a 'Global Asian Era' (GAE). If this is the case, then we may expect that many of its defining characteristics will be shaped, at least initially, by its currently principal driving force, namely the Chinese form of capitalism. Henderson identifies what might be the key features of Chinese capitalism, as a political economy and social formation, which are likely to give an emergent GAE its particular character. With this in mind, and critically engaging with 'development' and 'transition' discourses of various stripes, he concludes that we need to re-conceptualise and theorise global change around the dialectics of 'transformation'.

Following in a related vein in Chapter 12, Minglu Chen and David S.G. Goodman examine China's recent developmental experience and discuss 
what have been its lessons for other Asia-Pacific countries. They propose that in many ways China's economic growth and transformation since 1978 seems to have directly challenged theories of economic development. The key challenge to theories of modernisation, as previously understood, is that China's experience seems to suggest that authoritarian politics and economic restructuring can co-exist. Chen and Goodman note that China's economic reform process has shown that the most remarkable feature of the country's development is not simply the continuation of Chinese Communist Party rule but rather its adaptability. While, they argue, China's rise has furthermore posed serious challenges to ideas of modernisation and economic development, the international influence of the 'China model' rests on the extent to which China's experience is seen to be presenting an alternative path that others may follow, and not simply seen to be the result of unique circumstances. From that perspective the China model rapidly becomes of little use to the developing Asia-Pacific. Goodman and Chen propose there are essentially three problems. First, there is very little agreement about what constitutes the China model. Second, China's development of the last three decades is for the most part the result of highly specific circumstances. Third and last, where there are lessons to be learnt there is little in the experience of the developing AsiaPacific to suggest that those lessons can readily and generally be begun to be replicated.

In Chapter 13, Richard P. Appelbaum and Rachel Parker make a close examination of China's move to high-tech innovation, and what the policy implications of this are for other Asia-Pacific nations, especially the United States. High-tech industry development has long involved debates concerning the extent to which states should be a proactive agent in the process, and what forms of involvement this may or should take. Appelbaum and Parker examine the steps that China has recently taken to 'leapfrog development' through a series of government programmes intended to foster indigenous innovation. They examine the implemented programmes that serve this purpose and form the basis of China's hightech industrial policies, comparing this with the US's approach both generally and regarding key emerging sectors such as nanotechnology. Appelbaum and Parker then critically examine the claim that China is becoming a political as well as economic superpower, before turning to a discussion of China's global and regional future. With regard to the former, they focus on US-China relations, in particular the reaction of the US government and leading businesses to what is often perceived as the Chinese threat. Concerning the regional dimension to this, they examine some of the tensions between China and its neighbours in East Asia and the Asia-Pacific. 
Turning to important issues of development assistance and poverty alleviation globally, James Reilly considers in Chapter 14 whether a Northeast Asian model of foreign aid is becoming apparent given the well established importance of Japanese aid donorship, and the growing importance of emerging Asian donors such as China and South Korea. He notes that in the realm of official development assistance (ODA) there is a growing pluralism among aid donors and approaches that has emerged, representing the most significant challenge to Western aid orthodoxy in decades. In response, the still very Western-dominated Organisation for Economic Co-operation and Development's Development Assistance Committee (OECD-DAC) is striving to reshape international norms defining effective and appropriate ODA. Yet the DAC process faces a contradiction between being more inclusive by welcoming new members, collaborating with aid recipients and collaborating with non-DAC members, while also being more exclusive by codifying and promulgating selective norms on ODA. In this context, Reilly discusses to what extent are Northeast Asian aid donors challenging Western orthodoxies and prevailing norms of aid behaviour, especially given the distinctly different nature of their developmental political economies (see Chapter 3). For example, he cites that when having finally secured entry into the DAC in January 2010, South Korea pledged that it would formulate its own original model of development assistance that drew upon the country's own development experience and lessons learned, and that moreover would be aligned to its current national development strategies. Furthermore, in the same year, Chinese Premier Wen Jiabao remarked that a demonstratively successful model of Chinese development aid had now emerged, again like South Korea that derived largely from its own development path. Reilly explores the commonalties and contrasts between Japanese, Chinese and Korean approaches to ODA, thereby considering the extent to which a Northeast Asian model of development aid has formed. He discusses how such a model may impact on international norms of aid policy and practice.

Finally, Part V examines different societal perspectives on the AsiaPacific and the global system. In Chapter 15, Simen Andersen Øyen analyses the Chinese modernisation process - both its soft power potential and its tensions - through the experience of Shanghai's hosting of the 2010 World Exhibition (EXPO). He argues that China seeks to portray its path to modernity, wealth and stability as an alternative to the Western approach. Øyen contends that the 2010 Shanghai EXPO typified how the Chinese government would like to present itself and the 'modern face' of China. At the same time, the event revealed processes of political contestation and tension, new forms of disciplinarian process, and new shifting patterns of dominance and power relations in Chinese society. He argues that 
taken together with corresponding recent socio-political changes in China, the 2010 EXPO experience was indicative of broader shifts from 'hard' authoritarianism to a new and 'softer' authoritarianism in the country, this being particularly relevant in an international comparative sense to other developing countries in the Asia-Pacific and elsewhere. Protest movements and protest actions, as well as social civilising campaigns initiated by the authorities before and during the Shanghai EXPO, are expressions and indications of deep underlying processes of modernisation and civilising. Øyen contends that this corresponds to complex transnational socio-political and socio-cultural influences amongst nations in a deeper globalising world where China's own 'soft power' influences are being, and will be, increasingly felt.

Lastly, in Chapter 16, Christopher M. Dent broadens out the debate of Asia's international societal influences by considering how various recent developments in East Asian regionalism will impact on the formation of global or world society. He first notes that there remains much speculation concerning whether the 21st century will 'belong' to Asia. Dent argues that while there is value in considering Asia's future in the world system, ascribing 'ownership' of a future world epoch to any particular geopolitical power or construct may distract us from pursuing more crucial paths of scholarly enquiry. Given the escalating global-level challenges and problems that confront all humanity, Dent contends that it is more important to consider how Asia, and particularly East Asia - the Asia continent's most geopolitically significant and coherent regional entity may contribute to resolving these challenges. He argues that they are best addressed by a formative world society, and that deepening regionalism in East Asia is in some way inter-constitutive to world society formation. How the world's different nations, peoples and civilisations peacefully co-exist and co-operate with each other to deal with increasingly serious global-level challenges (for example environmental, poverty, and energy related) may be thought of prime meta-level issues of 21st-century international relations. These challenges are best addressed, according to Dent, by a collective worldwide response, and one that derives from a coherent association and unity of purpose between various forms of agency in the global system. The creation of different forms and structures of global governance represent an endeavour towards this end but something deeper is required. As a general principle, it is when society as a whole takes ownership and responsibility for problems affecting all its members, even though the impact of these problems is asymmetric, that they are most successfully resolved. Dent proposes that we should therefore work, at least in ideal terms, on the core premise that the 21 st century belongs to us all rather than a certain geopolitical power or powers. He argues 
that inherent to East Asia's deepening regionalism are particular forms of coherence - associative, integrational, organisational - that are also inherent to processes of world society formation. As such, regional community or society-building in East Asia may make potentially important contributions to the development of world society, and thereby concomitantly address global-level challenges. The same applies to the Asia-Pacific region as a whole, and this is one of many crucially important dimensions of the regionalism-globalisation relationship examined in this book.

\section{NOTE}

1. See, for example, Mack and Ravenhill (1994), McGrew and Brook (1998), and Aggarwal and Morrison (1998) for some of the most influential early assessments of Asia-Pacific institution-building; and Rüland et al. (2002), Feinberg (2003) and Ravenhill (2001) for comprehensive analyses of APEC's decisive contribution to Asia-Pacific regionalism.

\section{REFERENCES}

Aggarwal, V. and C. Morrison (eds) (1998), Asia-Pacific Crossroads. Regime Creation and the Future of APEC, New York: St. Martin's Press.

Balassa, B. (1961), The Theory of Economic Integration, Homewood, IL: Richard D. Irwin.

Beeson, M. (2009), Institutions of the Asia-Pacific: ASEAN, APEC and Beyond, London: Routledge.

Bobrow, D.B. (1999), 'Hegemonic Management: the US in the Asia-Pacific', The Pacific Review, 12(2), 173-97.

Borthwick, M. (1992), Pacific Century: The Emergence of Modern Pacific Asia, Sydney, NSW: Allen \& Unwin.

Coclanis, P. and T. Doshi (2000), 'Globalization in Southeast Asia', Annals of the American Academy of Political and Social Science, 570, 49-64.

Dent, C.M. (2006), New Free Trade Agreements in the Asia-Pacific, Basingstoke: Palgrave Macmillan.

Dent, C.M. (2008), East Asian Regionalism, Routledge: London.

Dieter, H. (2009), 'Changing patterns of regional governance: from security to political economy?', The Pacific Review, 22(1), 73-90.

Dosch, J. (2006), 'Does multilateralism work? European and American approaches to multilateral peace-building on the Korean peninsula', The Journal of Unification Studies, 28(1), 43-86.

Dosch, J. and O. Jacob (eds) (2010), Asia and Latin America. Economic, Political and Multilateral Relations, London: Routledge.

Elegant, R. (1990), Pacific Destiny: Inside Asia Today, New York: Crown Publishers.

Feinberg, R.E. (ed.) (2003), APEC as an Institution: Multilateral Governance in the Asia-Pacific, Singapore: Institute of Southeast Asian Studies.

Fukuyama, F. (1992), The End of History and the Last Man, New York: Free Press. 
Hameiri, S. and K. Jayasuriya (2011), 'Regulatory regionalism and the dynamics of territorial politics: the case of the Asia-Pacific region', Political Studies, 59(1), 20-37.

Harrison, J. (2006), 'Re-reading the new regionalism: a sympathetic critique', Space and Polity, 10(1), 21-46.

Hettne, B. (1999), 'Globalization and the new regionalism: the second great transformation', in B. Hettne, A. Inotai and O. Sunkel (eds), Globalism and the New Regionalism, London: Macmillan/New York: St Martin's Press, pp. 1-24.

Hettne, B. (2005), 'Beyond the "new" regionalism', New Political Economy, 10(4), 543-71.

Higgott, R. (1998), 'The Asian economic crisis: a study in the politics of resentment', New Political Economy, 3(3), 333-56.

Inter-American Development Bank (IDB) (2002), Beyond Borders: The New Regionalism in Latin America: Economic and Social Progress in Latin America, Washington, DC: IDB.

Jayasuriya, K. (2003), 'Introduction: governing the Asia-Pacific: beyond the "new regionalism", Third World Quarterly, 24(2), 199-215.

Mack, A. and J. Ravenhill (eds) (1994), Pacific Co-operation: Building Economic and Security Regimes in the Asia-Pacific Region, Sydney, NSW: Allen and Unwin.

Mahathir, M. and S. Ishihara (1995), The Voice of Asia: Two Leaders Discuss the Coming Century, Tokyo: Kodansha International.

McGrew, A. and C. Brook (eds) (1998), Asia-Pacific in the New World Order, London: Routledge.

Mitrany, D.A. (1943), A Working Peace System, London: Royal Institute of International Affairs.

Nye, J.S. (ed.) (1968), International Regionalism: Readings, Boston, MA: Little Brown.

Ravenhill, J. (2001), APEC and the Construction of Pacific Rim Regionalism, New York: Cambridge University Press.

Rüland, J., E. Manske and W. Draguhn (eds) (2002), Asia-Pacific Economic Co-operation (APEC): The First Decade, London: Routledge Curzon.

Väyrynen, R. (2003), 'Regionalism: Old and New', International Studies Review, 5(1), 25-51.

Viner, J. (1950), The Customs Union Issue, New York: Carnegie Endowment for International Peace.

Volz, U. (2010), Prospects for Monetary Co-operation and Integration in East Asia, Cambridge, MA: MIT Press. 
Jörn Dosch and Christopher M. Dent - 9781781004470 Downloaded from PubFactory at 04/26/2023 08:05:14AM 